\title{
Blood biochemistry and hormonal profiles of crossbred calves during hot-humid season under modified roofing systems
}

\author{
V. Maurya ${ }^{1 *}$, M. Singh ${ }^{2}$, P.K. Bharti ${ }^{3}$, V.P. Maurya ${ }^{4}$ and G.R. Channa ${ }^{5}$
}

${ }^{1}$ Livestock Production Management unit, Faculty of Veterinary \& Animal Sciences, Banaras Hindu University, U.P.; ${ }^{2}$ Livestock Production Management Section \& ${ }^{4}$ Division of Physiology and Climatology, ICAR-Indian Veterinary Research Institute, Izatnagar, Bareilly, U.P.; ${ }^{3}$ Livestock Production Management, ICAR-Mahatma Gandhi Integrated Farming Research Institute (ICAR-MGIFRI), Bihar; ICAR-Indian Veterinary Research Institute, Izatnagar, Bareilly, U.P.; ${ }^{5}$ Livestock Production Management, MAFSU, Parbhani, Maharashtra, India

*Corresponding Author email: drvipinmaurya@gmail.com

Journal of Livestock Science (ISSN online 2277-6214) 13: 67-75

Received on 27/11/21; Accepted on 1/2/22; Published on 5/2/22

doi. 10.33259/JLivestSci.2022.67-75

\begin{abstract}
Heat stress causes various alterations in normal blood biochemical \& hormonal parameters of the animals leading to decrease in comfort and hence production as well as productivity. Its impact is even more during hothumid climate. This study was therefore designed to witness the effect of various housing models on different blood parameters of crossbred calves during the rainy season in tropics. A total of eighteen crossbred calves (9-11 months old) were randomly selected and allocated in 3 groups viz. control (C): corrugated cemented sheet (CCS) as roofing material, T1: polycarbonate plastic sheet as roof and T2: polycarbonate roof with adjustable height. The aim of the study was to evaluate the effect of modified housing using different roofing materials on growth and physiological performance of calves during the rainy season. The THI at 9:00 am varied between $82.50 \pm 0.52$ to $86.30 \pm 0.43$ and at $2: 30 \mathrm{pm}$ between $85.67 \pm 0.63$ to $92.32 \pm 0.48$ during the season. The overall average temperature of shed was significantly $(\mathrm{P}<0.05)$ lower in $\mathrm{T} 2(28.18 \pm 0.11)$ than $\mathrm{T} 1(29.74 \pm 0.19)$ and $\mathrm{C}(30.55 \pm 0.06)$. Overall average relative humidity $(\%)$ was significantly $(\mathrm{P}<0.05)$ lower in $\mathrm{T} 2(77.08 \pm 0.31)$ as compared to $\mathrm{T} 1 \quad(82.10 \pm 0.76)$ and $\mathrm{C}$ (82.92 \pm 0.12$)$. Overall average temperature humidity index $(\mathrm{THI})$ was significantly $(\mathrm{P}<0.05)$ lower in $\mathrm{T} 2(76.56$ $\pm 0.23)$ followed by $\mathrm{T} 1(78.35 \pm 0.23)$ and $\mathrm{C}(79.30 \pm 0.18)$. Hemoglobin $(\mathrm{Hb})$ concentration $(\mathrm{g} / \mathrm{dl})$ was significantly higher $(\mathrm{P}<0.05)$ in $\mathrm{T} 2(11.18 \pm 0.31)$ as compared to $\mathrm{T} 1 \quad(10.36 \pm 0.47)$ and $\mathrm{C}(10.10 \pm 0.55)$. Serum Glutamic Oxaloacetic Transaminase (SGOT) level (IU/L) in C $(102.53 \pm 3.08)$ was significantly higher $(\mathrm{P}<0.05)$ followed by $\mathrm{T} 1(98.51 \pm 3.28)$ in comparison to $\mathrm{T} 2(91.73 \pm 2.41)$. No significant difference was found in the serum hormone levels $\left(\mathrm{T}_{3}, \mathrm{~T}_{4}\right.$ and cortisol) between the treatment groups. It may be inferred that the micro-environment was more conducive in T2 than control; hence the reflective polycarbonate roofing with adjusted higher height may be the desirable choice for animal housing in view of mitigating heat stress during the hot-humid climate.
\end{abstract}

Key words: Corrugated cemented sheet; Crossbred calves housing; Hot-humid Climate; Polycarbonate roofing; Serum bio-chemicals. 


\section{Introduction}

Hot-humid climate or rainy season is stressful livestock especially high yielding crossbred cattle. Increase in humidity depresses evaporative heat loss greatly and thus adds heat load to the animals. In combination with high temperature and humidity, the ability of the dairy animals to dissipate excess body heat is compromised which leads to depressed feed intake and consequent reduction in production performance. Change in microclimate not only affects the performance, feed intake and growth but also affect the serum biochemical levels in the body. The assessment of serum- biochemicals is one of the key indicators for identifying animals in stress (Kamal et al. 2018). Roof is an integral part of animal house and roofing materials prevent the direct heat from entering the house in different proportions and helps towards favourable micro-climate. Use of suitable roofing material and proper housing may provide a comfortable microenvironment to the crossbred calves in hot-humid climate (Maurya et al. 2018) leading to their better growth and performance (Lees et al. 2019). Most commonly used roofing materials include: thatch, clay tiles, reinforced cement concrete (RCC), galvanized iron (GI) sheets, asbestos, tin and plastic sheets, however there is limited to certain extent either due to limited durability or limited cost. These days low-cost house is need of the hour with higher durability, U.V protection which could ultimately modify the micro climatic conditions of the house.

Polycarbonate sheets being light and durable may be used as roofing materials for animal sheds. Moreover, it is being used in many agro-industries and commercial buildings by virtue of its higher strength, light weight, easy portability and installation. Adjustment of height of the roof during higher humidity and temperature may be another approach towards modifying the microenvironment for more comfort. Keeping in consideration these points, the study was designed to investigate the effect of roof modifications on blood biochemical and hormonal profiles of crossbred calves during hot humid season.

\section{Materials and Methods}

The present study was conducted on crossbred (Vrindavani) cattle calves maintained at the cattle and buffalo farm, IVRI, Izatnagar to evaluate the effect of modified housing using different roofing materials on blood biochemical and hormonal profiles of during the rainy season (July`2017 to September 2017). The Institute is located at an altitude of $169 \mathrm{~m}$ above mean sea level, at the latitude of $28.22^{\circ} \mathrm{N}$ latitude and $79.24^{\circ} \mathrm{E}$ longitudes. The climate of the place touches both the extremes of hot (approximately $45^{\circ} \mathrm{C}$ ) and cold (approximately $5^{\circ} \mathrm{C}$ ), and relative humidity $(\mathrm{RH})$ ranges between $15 \%$ and $99 \%$. Vrindavani cattle is crossbred strain of India developed by ICAR-IVRI, Izatnagar. It has exotic inheritance of Holstein-Friesian, Brown Swiss, Jersey and indigenous inheritance of Hariana cattle (Singh et al. 2011). A total of eighteen female calves (9-11 months old) were randomly selected and allocated in 3 groups viz. control (C); The animals were kept in a loose housing system with $2 \mathrm{~m}^{2}$ space per animal in covered area and $4 \mathrm{~m}^{2}$ per animal in open area. Corrugated cemented sheet was used as roofing material. Treatment 1 (T1): Polycarbonate sheet as roofing material, all other aspects of house was kept same as C; Treatment 2 (T2): Polycarbonate sheet as roofing material with adjustable height. Height at eaves was kept $2.5-2.7$ $\mathrm{m}$ and the height at centre was $3.5 \mathrm{~m}$ (for hot-humid period). The roof was arranged like a ridge system of ventilation for hot air in shed to pass from the roof itself. A gap of two feet was provided for ridge ventilation with one side of roof overhanging the other, all other aspects of house was kept same as C \& T1. The difference in the height of the roof in $\mathrm{T} 2$ from $\mathrm{C} \& \mathrm{~T} 1$ was around $0.3 \mathrm{~m}$ at eaves and $0.6 \mathrm{~m}$ at centre. The animals were maintained under iso-managerial conditions of management, feeding with semi- intensive system and housed in a wellventilated brick cemented loose house with non-slippery floor open byre with standard space as per Indian Standard. The calves were offered standard ration having green and dry fodder along with concentrate in all the groups.

Temperature of sheds was measured by maximum and minimum thermometer twice daily at forenoon (9:00 am) and afternoon $(2: 30 \mathrm{pm})$. Simultaneously the relative humidity $(\mathrm{RH})$ of sheds was measured using dry and wet bulb thermometer twice daily. Temperature humidity index (THI) was calculated as per McDowell (1972) using the following formula: $\mathrm{THI}=0.72$ (wet bulb temperature + dry bulb temperature) +40.6 . Inner surface temperature (ST) of roof was recorded by infrared thermometer (ebro, TFI 220) at 9:00 am and 2:30 pm for three consecutive days at fortnightly interval.

Blood samples from experimental calves were collected at monthly interval by puncturing jugular vein following aseptic measures. Serum was separated and stored at $-20^{\circ} \mathrm{C}$ for further analyses. All the serum samples were analyzed in Nuclear Research Laboratory (NRL), IVRI, Izatnagar. Fresh blood samples were utilized for hematological estimation. Erythrocytes and leukocytes were counted using hemocytometer (Neubauer's counting chamber). The blood Hb was estimated by Drabkin's method. Packed cell volume (\%) in the blood samples was 
determined by using microhematocrit method. Serum biochemical level, i.e glucose, total protein, albumin, globulin, creatinine, Serum Glutamic Oxaloacetic Transaminase (SGOT) and Serum Glutamic Pyruvic Transaminase (SGPT) were estimated using the kit supplied by (Coral Clinical Systems, India) and hormones viz. Cortisol, Serum Triiodothyronine $\left(\mathrm{T}_{3}\right)$ and Serum Thyroxin $\left(\mathrm{T}_{4}\right)$ were estimated using the kit supplied by (NovaTec, Immundiagnostica, GMBH, Germany). The data obtained from the study was analyzed using standard statistical methods as described by Snedecor and Cochran (1994).

\section{Results and Discussion}

\section{Macro climate during rainy season}

The solar radiation ranged from $149.33 \pm 16.05$ to $182.89 \pm 11.44 \mathrm{~W} / \mathrm{m} 2$ during the course of the experiment, whereas wind speed varied from $0.61 \pm 0.14$ to $0.87 \pm 0.08 \mathrm{~m} / \mathrm{s}$. The mean ambient temperature ranged between $27.64 \pm 0.57$ to $32.56 \pm 0.51^{\circ} \mathrm{C}$. The ambient temperature during the experimental period at 9:00 am ranged between $25.11 \pm 0.40$ to $27.24 \pm 0.22{ }^{\circ} \mathrm{C}$. The mean RH during the observation period ranged between $64.66 \pm 1.54 \%$ to $75.35 \pm 1.81 \%$. The THI at 9:00 am varied between $82.50 \pm 0.52$ to $86.30 \pm 0.43$ and at 2:30 pm between 85.67 \pm 0.63 to $92.32 \pm 0.48$. The mean THI during the observation period was ranged between $84.09 \pm 0.56$ to $89.31 \pm 0.41$. The macroclimatic conditions were more stressful during afternoon as compared to morning hours.

\section{Microenvironment of sheds}

\section{Temerature $\left({ }^{0} \mathrm{C}\right)$ of the shed}

The temperature at 9:00 am during the first fortnight was $25.97 \pm 0.55,24.93 \pm 0.46$ and $22.63 \pm 0.63^{\circ} \mathrm{C}$, which decreased to $23.73 \pm 0.68,23.70 \pm 0.82$ and $21.17 \pm 0.20{ }^{\circ} \mathrm{C}$ under $\mathrm{C}, \mathrm{T} 1$ and $\mathrm{T} 2$ respectively, during the last fortnight, whereas the corresponding values at 2:30 pm during the first fortnight decreased from $36.40 \pm 0.31,35.27 \pm 0.37$ and $33.23 \pm 0.39$ to $35.43 \pm 0.72,35.07 \pm 0.39$ and $32.27 \pm 0.37$, respectively, during last fortnight. The overall minimum temperature at 9:00 am was $25.34 \pm 0.09,24.54 \pm 0.20$ and $22.86 \pm 0.17{ }^{\circ} \mathrm{C}$, whereas at $2: 30 \mathrm{pm} 35.75 \pm 0.15$, $34.94 \pm 0.32$ and $33.37 \pm 0.15{ }^{\circ} \mathrm{C}$ in $\mathrm{C}, \mathrm{T} 1$ and $\mathrm{T} 2$ respectively. The overall average temperature was significantly $(\mathrm{P}<0.05)$ lower in T2 $(28.18 \pm 0.11)$ as compared to T1 $(29.74 \pm 0.19)$ and $\mathrm{C}(30.55 \pm 0.06)$. The temperature of sheds at 9:00 a.m. and 2:30 p.m. were significantly $(\mathrm{P}<0.05)$ lower in $\mathrm{T} 2$ followed by $\mathrm{T} 1$ and highest in $\mathrm{C}$, during all the fortnights.

In T2 lower temperature of shed than control was recorded during rainy season which may be due to higher height of house and ridge system of ventilation which allowed the hot air accumulated to pass from the roof itself and hence maintained a slightly lower shed temperature. Increasing the height of shed with ridge ventilation might have helped to dissipate heat easily in T2. The present findings are in agreement with Kamal et al. (2013) and Jat et al. (2005) who reported higher shed temperature of asbestos sheet roofing material in comparison to thatched roof, mud-plaster roof and agro-net sheet roof house during rainy season. Asbestos roofed houses had higher temperature than the tile roofed house (Sivakumar, 2017). However, in contrary to our results Roy and Chatterjee, (2010) reported that polythene sheet roof had the lowest minimum and higher maximum temperature as compared to GI sheet, and tile roof shade structure in rainy season.

\section{Relative humidity (\%) of sheds}

The RH at 9:00 am during the first fortnight in C, T1 and T2 was $80.80 \pm 1.22,80.05 \pm 1.87$ and $76.80 \pm 2.04$ $\%$, which increased to $86.72 \pm 1.52,85.72 \pm 2.23$ and $79.70 \pm 2.65 \%$ at last fortnight. Similarly, $\mathrm{RH}$ at $2: 30 \mathrm{pm}$ increased from $73.50 \pm 0.92,72.70 \pm 1.29$ and $69.60 \pm 1.92 \%$ to $83.51 \pm 1.98,83.51 \pm 1.29$ and $73.23 \pm 1.06 \%$ for $\mathrm{C}$, T1 and $\mathrm{T} 2$ respectively. The overall average $\mathrm{RH}$ was $82.92 \pm 0.12,82.10 \pm 0.76$ and $77.08 \pm 0.31 \%$ in $\mathrm{C}$, T1 and T2 respectively during the rainy season. Irrespective of treatment $\mathrm{RH}$ at 9:00 am was significantly $(\mathrm{p}<0.05)$ higher than at 2:30 pm. The RH at 9:00 am and 2:30 pm was significantly $(\mathrm{p}<0.05)$ higher in $\mathrm{C}$, followed by $\mathrm{T} 1$ as compared to $\mathrm{T} 2$ during all the fortnights. The negative diurnal changes in RH were observed in all the shades during rainy season due to rise in environmental temperature from morning to mid day as routine phenomenon as reported earlier also by Kaur and Singh, (2004). The Present finding are also supported by Roy and Chatterjee, (2010), who reported significantly higher in morning and evening in all the shelters (GI sheet, tiles and polythene shade) during rainy season indicating higher stress on the animals, whereas, Das, (2012) observed highest RH in GI sheet roof during rainy season as compared to polythene and tile roof. The RH under T2 was found to be minimum, which might be 
due to the fact that this system of housing allowed the floor to become dry quickly and provided proper ventilation. The present findings are in accordance with earlier reports (Kamal et al. 2013) who observed higher humidity in asbestos roofed house as compared to thatch, tree and agro-net. Asbestos roofed houses had higher relative humidity than the tile roofed house (Sivakumar, 2017).

\section{Temperature humidity index of sheds}

The THI recorded fortnightly at 9:00 am and 2:30 pm during the experimental period under different roofing materials are presented in (Figure-1). The overall THI at 9:00 am in C, T1 and T2 was 77.28 $\pm 0.20,76.69 \pm$ 0.24 and $74.34 \pm 0.23$, whereas at $2: 30$ pm was $81.33 \pm 0.19,80.01 \pm 0.24$ and $78.78 \pm 0.23$, respectively. Overall average THI was significantly $(\mathrm{P}<0.05)$ lower in $\mathrm{T} 2(76.56 \pm 0.23)$ followed by $\mathrm{T} 1(78.35 \pm 0.23)$ and $\mathrm{C}(79.30 \pm$ $0.18)$. The THI at 9:00 am was significantly $(\mathrm{p}<0.05)$ lower from THI at $2: 30 \mathrm{pm}$ in all the treatments groups. Lower values of THI in T2 compared to control indicates more conducive micro-environment, which may be due to less heat penetration and effective ventilation viz. higher height of roof.

The present finding is also supported by Khongdee, (2008), who concluded that the difference between maximum and minimum THI during the rainy season was lower suggesting that the dairy cows were exposed to heat stress conditions more consistently during the rainy season. However, the shade of polypropylene had a significantly lower ambient temperature and THI $(\mathrm{P}<0.05)$ for $5 \mathrm{~h}$ and $5 \mathrm{~h} 30$ minute respectively, a difference most likely due to the reduction in re-radiated heat in the Shaded shed. Pusta et al., (2006) reported higher THI (>72) in pasture heifers in the month of rainy season as compared to cows during lactation. Jat et al., (2005) recorded higher THI in asbestos in morning $(81.52 \pm 0.35)$ and evening $(85.71 \pm 0.51)$ as compared to mud plaster and less in thatch during rainy season, whereas, Das, (2012) and Roy and Chatterjee, (2010) observed higher THI (83.48 \pm 0.52$)$ under GI sheet roof.

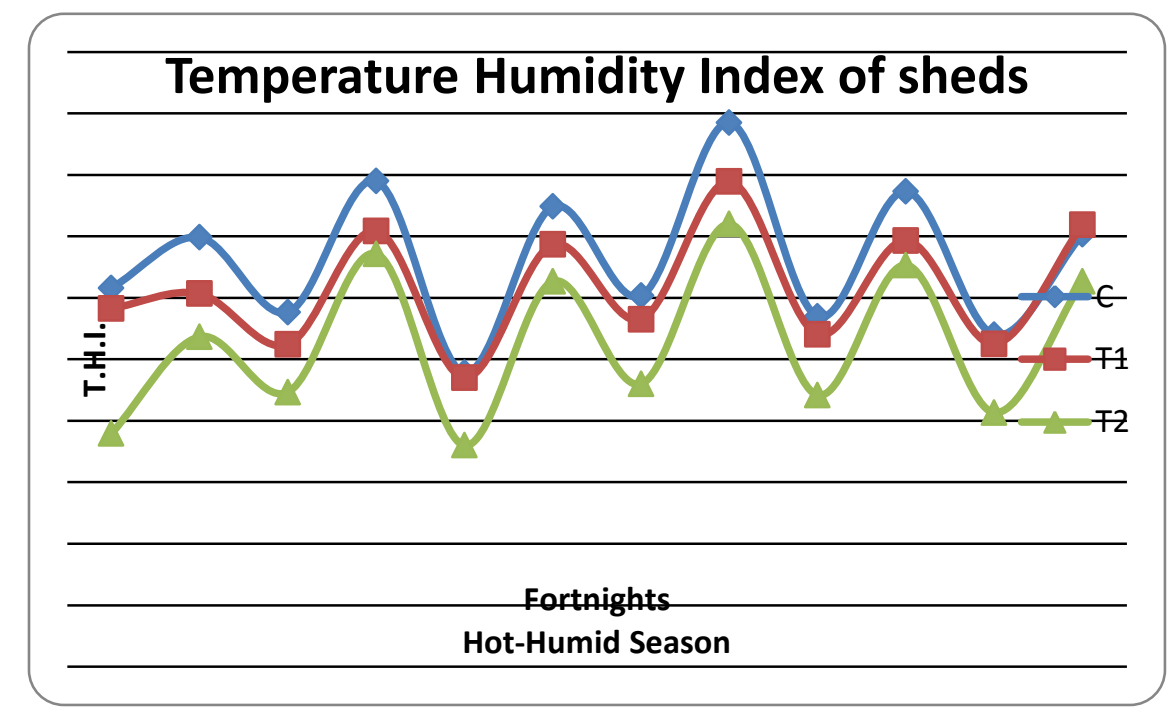

Fig 1: Temperature Humidity Index of experimental sheds during rainy season.

\section{Inner surface temperature $\left({ }^{\circ} \mathrm{C}\right)$ of roofing materials}

The inner surface temperature of roof for different sheds has been presented in Table 1 . The overall inner surface temperature of roofs at 9:00 a.m. and 2:30 p.m. were significantly lower $(\mathrm{p}<0.05)$ in T2 followed by $\mathrm{T} 1$ and highest in C. Polycarbonate being reflective and UV resistant might have allowed minimum heat to pass and thus provided better microclimate as compared to control in $\mathrm{T} 2$ and $\mathrm{T} 1$. The present findings are in agreement with Kamal et al. (2013) who recorded higher inner surface temperature of asbestos sheet in comparison to thatched roof and agro-net roof during rainy season. 
Table 1: inner surface temperature $\left({ }^{\circ} \mathrm{C}\right)$ of different roofing materials

\begin{tabular}{|l|l|l|l|l|}
\hline Fortnight & Time & $\begin{array}{l}\text { Corrugated cemented } \\
\text { sheet roof (C) }\end{array}$ & $\begin{array}{l}\text { Polycarbonate } \\
\text { Roof (T2) }\end{array}$ & $\begin{array}{l}\text { Roof with Adjustable } \\
\text { height (T3) }\end{array}$ \\
\hline F1 & $9: 00 \mathrm{am}$ & $40.83 \pm 0.44^{\mathrm{a}}$ & $39.50 \pm 0.29^{\mathrm{ab}}$ & $38.87 \pm 0.47^{\mathrm{b}}$ \\
\hline & $2: 30 \mathrm{pm}$ & $48.97 \pm 0.62$ & $47.30 \pm 0.49$ & $46.87 \pm 0.47$ \\
\hline & Avg & $44.09 \pm 0.48^{\mathrm{a}}$ & $43.82 \pm 0.22^{\text {ab }}$ & $42.87 \pm 0.47^{\mathrm{b}}$ \\
\hline F2 & $9: 00 \mathrm{am}$ & $40.50 \pm 0.29$ & $40.48 \pm 0.29$ & $39.01 \pm 0.38$ \\
\hline & $2: 30 \mathrm{pm}$ & $49.17 \pm 0.64$ & $48.40 \pm 0.45$ & $47.53 \pm 0.29$ \\
\hline & Avg & $44.83 \pm 0.38$ & $44.43 \pm 0.36$ & $43.27 \pm 0.32$ \\
\hline F3 & $9: 00 \mathrm{am}$ & $40.81 \pm 0.43^{\mathrm{a}}$ & $39.57 \pm 0.32^{\mathrm{ab}}$ & $39.31 \pm 0.17^{\mathrm{b}}$ \\
\hline & $2: 30 \mathrm{pm}$ & $48.82 \pm 0.59$ & $47.43 \pm 0.62$ & $47.03 \pm 0.44$ \\
\hline & Avg & $44.82 \pm 0.38^{\mathrm{a}}$ & $43.50 \pm 0.20^{\mathrm{ab}}$ & $43.17 \pm 0.29^{\mathrm{b}}$ \\
\hline F4 & $9: 00 \mathrm{am}$ & $40.80 \pm 0.18^{\mathrm{a}}$ & $39.75 \pm 0.34^{\mathrm{ab}}$ & $39.16 \pm 0.30^{\mathrm{b}}$ \\
\hline & $2: 30 \mathrm{pm}$ & $48.67 \pm 1.16^{\mathrm{a}}$ & $48.23 \pm 0.15^{\text {ab }}$ & $46.63 \pm 0.86^{\mathrm{b}}$ \\
\hline & Avg & $44.74 \pm 0.61^{\mathrm{a}}$ & $43.99 \pm 0.24^{\mathrm{ab}}$ & $42.90 \pm 0.56^{\mathrm{b}}$ \\
\hline F5 & $9: 00 \mathrm{am}$ & $39.10 \pm 0.59$ & $37.30 \pm 0.85$ & $36.50 \pm 0.66$ \\
\hline & $2: 30 \mathrm{pm}$ & $48.80 \pm 0.62$ & $47.67 \pm 0.28$ & $46.03 \pm 0.55$ \\
\hline & Avg & $43.95 \pm 0.19$ & $42.48 \pm 0.53$ & $41.27 \pm 0.45$ \\
\hline F6 & $9: 00 \mathrm{am}$ & $40.33 \pm 0.33$ & $38.83 \pm 0.73$ & $38.11 \pm 1.16$ \\
\hline & $2: 30 \mathrm{pm}$ & $49.20 \pm 1.29^{\mathrm{a}}$ & $49.03 \pm 1.06^{\mathrm{a}}$ & $47.93 \pm 0.62^{\mathrm{b}}$ \\
\hline & Avg & $44.77 \pm 0.49$ & $43.92 \pm 0.23$ & $43.02 \pm 0.88$ \\
\hline Overall & $9: 00 \mathrm{am}$ & $40.40 \pm 0.04^{\mathrm{a}}$ & $39.24 \pm 0.24^{\mathrm{ab}}$ & $38.49 \pm 0.28^{\mathrm{b}}$ \\
\hline & $2: 30 \mathrm{pm}$ & $48.94 \pm 0.56^{\mathrm{a}}$ & $48.14 \pm 0.33^{\text {ab }}$ & $47.02 \pm 0.19^{\mathrm{b}}$ \\
\hline & Avg & $44.67 \pm 0.27^{\mathrm{a}}$ & $43.69 \pm 0.14^{\mathrm{ab}}$ & $42.75 \pm 0.19^{\mathrm{b}}$ \\
\hline
\end{tabular}

Means values between 9:00 am \& 2:30 pm differ significantly $(\mathrm{P}<0.05)$ within the treatments Means bearing different Superscript differ significantly $(\mathrm{P}<0.05)$ row wise

\section{Blood parameters}

The $\mathrm{Hb}$ of crossbred calves to different house modifications has been presented in Table 2. Calves in T2 group had significantly $(\mathrm{P}<0.05)$ more $\mathrm{Hb}$ as compared to $\mathrm{T} 1$ and $\mathrm{C}$. This might be due to the provision of healthy micro-environment due to respective housing modification as compared to other groups which increased the DMI of the respective group, resulted in more $\mathrm{Hb}$ level. The normal $\mathrm{Hb}$ values in calves vary from 5.6 to $12.5 \mathrm{~g} / \mathrm{dl}$ (Roland et al. 2014). Our findings are similar to Kamal, (2013) who also reported a significant increase in $\mathrm{Hb}$ in calves kept in thatch and agro-net as compared to asbestos during rainy season. Sinha et al. (2019) also found significantly higher $\mathrm{Hb}$ concentration $(\mathrm{g} / \mathrm{dl})$ and white blood corpuscles $(103 / \mathrm{cmm})$ in the crossbred cows housed with foggers plus fan $(10.54 \pm 0.36$ and $12.35 \pm 0.64)$ as compared to cows housed with sprinklers $(9.52 \pm 0.43$ and10.88 \pm 0.57 ) during the summer. Reena et al. (2016) also found significant increase in Hb conc. of calves in more comfortable sheds having cooler microenvironment during the rainy season. The Total Erythrocyte Count, Total Leukocyte count and Packed Cell Value of crossbred calves to different housing modifications has been presented in Table 2. However, no significant difference was observed among the three groups during rainy season. Our findings are in accordance with Verma, (2015) who reported non-significant difference in the heifers kept under different cooling systems during rainy season. The values of TEC, TLC and PCV in present study was under normal range $\left(4.9-7.5 \times 10^{6} / \mu \mathrm{L} \quad 5-12 \times 10^{3} / \mu \mathrm{L}\right.$ and $22-38 \%$ respectively) (Roland $e t$ al. 2014).

\section{Serum biochemical parameters of calves}

The effect of shade materials on various biochemical parameters viz. glucose, total protein, albumin, globulin and creatinine at monthly interval has been presented in table2. The results are in accordance with Kamal, (2013) who reported non-significant difference in the Vrindavani calves kept in thatch, agro-net and asbestos during rainy season. Serum glucose value of present finding is supported by Shrikhande et al. (2008) in cattle during rainy season.

The total serum protein values for $\mathrm{C}, \mathrm{T} 1$ and $\mathrm{T} 2$ grouped calves were $7.09 \pm 1.12,6.98 \pm 0.98$ and $7.12 \pm 0.77$ $\mathrm{g} / \mathrm{dl}$ respectively. The table revealed that there was non-significant difference between the groups. The present value for total serum protein is in support with Shrikhande et al. (2008) and Hooda and Naqvi (1990) during rainy season. The values of serum albumin and globulin were found to be non significant $(\mathrm{P}<0.05)$ within the groups. The present 
Table 2: Effect of roofing materials on Blood parameters of experimental calves

\begin{tabular}{|c|c|c|c|c|c|c|c|c|c|c|c|c|}
\hline & \multicolumn{3}{|c|}{ July } & \multicolumn{3}{|c|}{ Aug } & \multicolumn{3}{|c|}{ Sept } & \multicolumn{3}{|c|}{ Overall } \\
\hline & C & T1 & $\mathrm{T} 2$ & $\mathrm{C}$ & T1 & $\mathrm{T} 2$ & $\mathrm{C}$ & T1 & $\mathrm{T} 2$ & $\mathrm{C}$ & $\mathrm{T} 1$ & $\mathrm{~T} 2$ \\
\hline $\begin{array}{l}\text { Hemoglobin } \\
(\mathrm{g} / \mathrm{dl})\end{array}$ & $9.56 \pm 0.51$ & $9.7 \pm 0.63$ & $10.35 \pm .47$ & $10.89 \pm 0.78$ & $10.5 \pm 0.52$ & $11.5 \pm 0.63$ & $9.87 \pm 0.92$ & $10.89 \pm 0.69$ & $11.7 \pm 0.56$ & $10.10 \pm 0.55^{\mathrm{a}}$ & $10.36 \pm 0.47^{\mathrm{a}}$ & $11.18 \pm 0.31^{\mathrm{b}}$ \\
\hline $\operatorname{TEC}\left(10^{6} / \mu \mathrm{L}\right)$ & $5.30 \pm 0.32$ & $5.40 \pm 0.19$ & $5.40 \pm 0.21$ & $5.80 \pm 0.17$ & $5.17 \pm 0.11$ & $6.26 \pm 0.14$ & $5.45 \pm 0.11$ & $5.96 \pm 0.18$ & $6.42 \pm 0.12$ & $5.52 \pm 0.09$ & $5.51 \pm 0.04$ & $6.03 \pm 0.07$ \\
\hline $\operatorname{TLC}\left(10^{3} / \mu \mathrm{L}\right)$ & $9.76 \pm 0.77$ & $9.54 \pm 0.53$ & $11.60 \pm 0.70$ & $10.52 \pm 0.63$ & $10.52 \pm 0.46$ & $11.45 \pm 0.51$ & $9.53 \pm 0.94$ & $11.18 \pm 0.36$ & $10.72 \pm 0.42$ & $9.94 \pm 0.53$ & $10.41 \pm 0.25$ & $11.26 \pm 0.22$ \\
\hline PCV (\%) & $\begin{array}{l}29.10 \\
\pm 1.23 \\
\end{array}$ & $30.05 \pm 0.92$ & $31.80 \pm 1.06$ & $32.67 \pm 0.98$ & $31.90 \pm 1.15$ & $34.50 \pm 1.08$ & $30.56 \pm 1.86$ & $32.42 \pm 1.04$ & $34.80 \pm 0.81$ & $30.78 \pm 0.98$ & $31.46 \pm 0.73$ & $33.70 \pm 0.67$ \\
\hline $\begin{array}{l}\text { Glucose } \\
(\mathrm{mg} / \mathrm{dl})\end{array}$ & $\begin{array}{l}53.70 \\
\pm 6.30\end{array}$ & $54.60 \pm 5.83$ & $55.24 \pm 4.78$ & $50.80 \pm 3.98$ & $53.22 \pm 4.88$ & $52.70 \pm 3.79$ & $54.89 \pm 4.53$ & $56.46 \pm 3.32$ & $55.89 \pm 3.08$ & $53.13 \pm 3.30$ & $54.73 \pm 2.83$ & $54.61 \pm 2.78$ \\
\hline \multicolumn{13}{|c|}{ Serum Biochemicals } \\
\hline $\begin{array}{l}\text { Total } \\
\text { Protein }(\mathrm{g} / \mathrm{dl})\end{array}$ & $6.91 \pm 1.18$ & $6.75 \pm 1.78$ & $6.86 \pm 2.01$ & $7.09 \pm 1.79$ & $7.04 \pm 1.21$ & $7.18 \pm 0.56$ & $7.26 \pm 2.71$ & $7.15 \pm 0.85$ & $7.33 \pm 1.08$ & $7.09 \pm 1.12$ & $6.98 \pm 0.98$ & $7.12 \pm 0.77$ \\
\hline Ablumin (g/dl) & $3.51 \pm 0.29$ & $3.29 \pm 0.12$ & $3.57 \pm 0.15$ & $3.54 \pm 0.32$ & $3.46 \pm 0.09$ & $3.73 \pm 0.22$ & $3.70 \pm 0.41$ & $3.58 \pm 0.26$ & $3.72 \pm 0.12$ & $3.58 \pm 0.19$ & $3.44 \pm 0.08$ & $3.67 \pm 0.07$ \\
\hline Globulin (g/dl) & $3.40 \pm 0.38$ & $3.46 \pm 0.34$ & $3.29 \pm 0.41$ & $3.55 \pm 0.29$ & $3.58 \pm 0.23$ & $3.45 \pm 0.39$ & $3.56 \pm 0.59$ & $3.57 \pm 0.30$ & $3.61 \pm 0.52$ & $3.50 \pm 0.23$ & $3.54 \pm 0.12$ & $3.45 \pm 0.21$ \\
\hline $\begin{array}{l}\text { Creatinine } \\
(\mathrm{mg} / \mathrm{dl})\end{array}$ & $1.09 \pm 0.14$ & $1.07 \pm 0.12$ & $1.03 \pm 0.14$ & $1.25 \pm 0.11$ & $1.13 \pm 0.11$ & $1.09 \pm 0.12$ & $0.91 \pm 0.09$ & $0.85 \pm 0.08$ & $0.77 \pm 0.09$ & $1.08 \pm 0.08$ & $1.02 \pm 0.07$ & $0.96 \pm 0.06$ \\
\hline \multicolumn{13}{|c|}{ Serum Enzymes } \\
\hline SGOT(IU/L) & $\begin{array}{l}99.10 \\
\pm 4.41^{\text {a }}\end{array}$ & $\begin{array}{l}101.07 \\
\pm 8.45^{\mathrm{a}}\end{array}$ & $\begin{array}{l}82.92 \\
\pm 5.18^{\mathrm{b}}\end{array}$ & $\begin{array}{l}103.30 \\
\pm 5.60^{\mathrm{a}}\end{array}$ & $\begin{array}{l}93.67 \\
\pm 3.71^{\mathrm{b}}\end{array}$ & $\begin{array}{l}92.51 \\
\pm 3.51^{\mathrm{b}}\end{array}$ & $\begin{array}{l}105.20 \\
\pm 5.45^{\mathrm{a}}\end{array}$ & $100.81 \pm 4.76^{\mathrm{b}}$ & $99.78 \pm 3.97^{\mathrm{b}}$ & $102.53 \pm 3.08$ & $98.51 \pm 3.28^{b}$ & $91.73 \pm 2.41^{\circ}$ \\
\hline SGPT(IU/L) & \begin{tabular}{|l}
36.61 \\
\pm 5.89 \\
\end{tabular} & \begin{tabular}{|l}
35.70 \\
\pm 5.04 \\
\end{tabular} & \begin{tabular}{|l|}
35.21 \\
\pm 4.17 \\
\end{tabular} & \begin{tabular}{|l|}
34.41 \\
\pm 7.10 \\
\end{tabular} & $\begin{array}{l}35.95 \\
\pm 4.35 \\
\end{array}$ & $\begin{array}{l}34.18 \\
\pm 5.38 \\
\end{array}$ & \begin{tabular}{|l}
6.6 \\
$2 \pm 5.04^{\mathrm{a}}$
\end{tabular} & $37.81 \pm 5.72^{a}$ & $32.38 \pm 4.73^{b}$ & $35.88 \pm 3.84$ & $36.48 \pm 1.71$ & $33.92 \pm 3.30$ \\
\hline \multicolumn{13}{|c|}{ Serum Hormones } \\
\hline $\begin{array}{l}\text { Cortisol } \\
(\mathrm{nM} / \mathrm{L})\end{array}$ & \begin{tabular}{|l|}
17.89 \\
\pm 1.54
\end{tabular} & $16.78 \pm 1.88$ & $16.71 \pm 1.72$ & $20.05 \pm 1.42$ & $19.42 \pm 1.09$ & $17.90 \pm 2.01$ & $19.56 \pm 1.55$ & $19.83 \pm 0.84$ & $18.76 \pm 0.64$ & $19.17 \pm 0.96$ & $18.68 \pm 1.02$ & $17.79 \pm 0.91$ \\
\hline $\mathrm{T}_{3}(\mathrm{nM} / \mathrm{L})$ & $2.01 \pm 0.25$ & $2.34 \pm 0.16$ & $1.98 \pm 0.19$ & $1.65 \pm 0.26$ & $1.97 \pm 0.24$ & $1.57 \pm 0.43$ & $2.09 \pm 0.41$ & $1.78 \pm 0.31$ & $2.54 \pm 0.96$ & $1.92 \pm 0.10$ & $2.03 \pm 0.09$ & $2.03 \pm 0.11$ \\
\hline $\mathrm{T}_{4}(\mathrm{nM} / \mathrm{L})$ & \begin{tabular}{|l|}
67.85 \\
\pm 4.51 \\
\end{tabular} & $64.21 \pm 4.92$ & $63.45 \pm 4.65$ & $72.90 \pm 5.33$ & $69.82 \pm 3.50$ & $67.85 \pm 4.45$ & $64.87 \pm 3.51$ & $59.75 \pm 3.39$ & $63.30 \pm 3.92$ & $68.56 \pm 2.41$ & $64.59 \pm 2.17$ & $64.87 \pm 1.42$ \\
\hline
\end{tabular}

Means bearing different superscript in a row differ significantly $(\mathrm{P}<0.05)$ 
values for serum albumin and globulin during rainy season are in accordance with the values reported by Shrikhande et al. (2008). Kamal, (2013) also reported non-significant difference in serum albumin values in crossbred calves kept under thatch, agronet, tree and asbestos during rainy season.

The serum creatinine values for $\mathrm{C}, \mathrm{T} 1$ and $\mathrm{T} 2$ were $1.08 \pm 0.08,1.02 \pm 0.07$ and $0.96 \pm 0.06 \mathrm{mg} / \mathrm{dl}$ respectively. The results suggested that there was no significant difference in the serum creatinine values among the groups. Moreover, in our study, the creatinine concentration in the calves in all the housing system was in the safe range. (Hammon et al. 2002).

\section{Serum enzymatic parameters}

The effect of house modifications on enzymes viz. SGOT and SGPT at monthly interval has been presented in table 2. The result suggested that there was significantly $(\mathrm{P}<0.05)$ higher SGOT level in $\mathrm{C}$ followed by $\mathrm{T} 1$ in comparison to T2. Though, the overall value for SGOT falls under the normal range (Radostits, et al, 2007). Higher level of serum SGOT in control and T1 grouped calves as compared to T2 might be due to higher temperature and THI which increased the serum SGOT activity in order to compensate the other negative effects of thermal stress on the physiological and biochemical homeostatic mechanisms. The finding is in agreement with Verma, (2015); Kamal, (2013) and Nazifi et al. (2003) as they reported an increase in serum SGOT activity during thermal stress.

Serum SGPT was found to be non significant $(\mathrm{P}<0.05)$ between the groups. This is in agreement with the report of Kamal (2013) who also reported non-significant difference in serum SGPT during rainy season under different shade materials. Nazifi et al., (2003) reported that there will be increase in serum SGPT activity at hot temperature as compared to cooler temperatures.

\section{Hormonal parameters}

The impact of different roofing materials during rainy season on Cortisol, $\mathrm{T}_{3}$ and $\mathrm{T}_{4}$ was studied fortnightly and presented in the table 2 . The serum cortisol levels for the three treatment groups, during rainy season was $19.17 \pm 0.96,18.68 \pm 1.02$ and $17.79 \pm 0.91 \mathrm{nmol} / \mathrm{l}$ for $\mathrm{C}, \mathrm{T} 1$ and $\mathrm{T} 2$ respectively. There was no significant difference within the groups, though the serum cortisol levels are higher in control followed by T1 as compared to T2. Serum total $\mathrm{T}_{3}$ level was $1.92 \pm 0.1,2.03 \pm 0.09$ and $2.03 \pm 0.11$, whereas total $\mathrm{T}_{4}$ values were $68.56 \pm 2.41,64.59 \pm 2.17$ and $64.87 \pm 1.42 \mathrm{nmol} / \mathrm{l}$ for $\mathrm{C}, \mathrm{T} 1$ and T2 respectively. From the table, it is clearly evident that the serum total $\mathrm{T}_{3}$ and total $\mathrm{T}_{4}$ did not differ significantly among the groups. Present finding is in agreement with Khongdee et al. (2010) who reported non-significant difference in $\mathrm{T}_{3}$ and $\mathrm{T}_{4}$ between the double shade polypropylene and single shade polypropylene cloth. Similarly, Kamal, (2013) also found nonsignificant $(\mathrm{P}<0.05)$ difference in in $\mathrm{T}_{3}$ and $\mathrm{T}_{4}$ in Vrindavani calves under different shade materials during rainy season. Vijayakumar (2005) found also nonsignificant difference in in $\mathrm{T}_{3}$ and $\mathrm{T}_{4}$ in buffalo heifers treated with fan and sprinkler to reduce heat stress and the control group. In contrast, Pusta et al., (2003) observed lower plasma concentration of both $\mathrm{T}_{3}$ and $\mathrm{T}_{4}$ when animals are heat stressed.

\section{Conclusion}

From the study, it may be inferred that the micro-environment was more conducive in the reflective polycarbonate roofing with adjusted higher height than corrugated cement roofing as the levels of stress biochemicals like cortisol and enzymes were found lower within the normal range. The polycarbonate sheets as roofing material may be the desirable choice for animal housing in view of mitigating heat stress during the hothumid climate.

\section{Acknowledgement}

The authors are thankful to the Director and all Joint Directors, ICAR-IVRI, Izatnagar, for providing the necessary infrastructural facilities for carrying out the experiment.

\section{Conflict of Interest}

The authors declare that they have no conflict of interest. 


\section{References}

1) Das, S.K. (2012). Effect of THI on milk production and physiological responses of crossbred cows during different months under the Agro climatic condition of Bihar. Indian Journal of Animal Sciences 65: 246249. 11.

2) Jat R P, Gupta L.R., Yadav B L. (2005). Effect of roof modifications in loose house on intake and utilization of nutrients in buffalo calves during rainy season. Indian Journal of Dairy Science 58: 54-57.

3) Hammon, H.M., Schiessler, G., Nussbaum, A., Blum, J.W. (2002). Feed intake patterns, growth performance, and metabolic and endocrine traits in calves fed unlimited amounts of colostrum and milk by automate, starting in the neonatal period. Journal of Dairy Science 85:3352-3362.

4) Hooda, O.K., Naqvi, S.M.K. (1990). Changes in some blood constituents in different breeds of sheep exposed to elevated temperature and feed restriction. Indian Veterinary Journal 67(12): 1121-1125.

5) Kamal R. (2013). Effect of different shed material on performance of Vrindavani calves. Ph. D. Thesis, IVRI (Deemed University), Izatnagar, India.

6) Kamal R, Dutt T, Patel B H M, Ram R P, Biswas P, Bharti P.K., Kaswan S. (2013). Effect of roofing materials on micro-climate in loose house for animals during rainy season, Veterinary World 6(8): 482-485

7) Kamal, R., Dutt, T., Patel, M., Dey A, Bharti, P K, Chandran PC. (2018). Heat stress and effect of shade materials on hormonal and behavior response of dairy cattle: a review. Tropical Animal Health and Production https://doi.org/10.1007/s11250-018-1542-6.

8) Kaur P and Singh J. (2004). Effect of building design on thermal comfort inside different dairy shelter. Livestock International 84(4): 2, 5-10.

9) Khongdee S. (2008). The effects of high temperature and housing modification on the productive and reproductive performance of dairy cows [Unpublished thesis submitted to Kasetsart university, Thailand].

10) Khongdee S, Sripoon S, Chousawai S, Hinch G, Chaiyabutr N, Markvichitr K and Vajrabukka C. (2010). The effect of modified roofing on the milk yield and reproductive performance of heat-stressed dairy cows under hot-humid conditions. Animal Science Journal 81(5): 606-611.

11) Lees AM, Sejian V, Wallage A L, Steel C C, Mader TL, Lees JC, Gaughan JB (2019). The Impact of Heat Load on Cattle Animals, 9(6), 322; https://doi.org/10.3390/ani9060322

12) Maurya V, Bharti PK, Singh M, Patel B, Gaur GK and Dutt T. 2018. Performance of crossbred calves under modified housing system during hot-humid season. Veterinary Practitioner. 20(1) 286-291

13) McDowell, R.E. 1972. Improvement of Livestock Production in Warm Climates. W.H. Freeman and Company, San Francisco. pp. 711

14) Nazifi S, Saeb M, Rowghani, E and Kaveh K. (2003). The influences of thermal stress on serum biochemical parameters of Iranian fat-tailed sheep and their correlation with triiodothyronine $\left(\mathrm{T}_{3}\right)$, thyroxine $\left(\mathrm{T}_{4}\right)$ and cortisol concentrations. Comparative Clinical Pathology 12(3): 135-139.

15) Pusta, D., Odagiu, A., Ersek, A. and Pascal, I. (2003). The variation of triiodothyronine $\left(\mathrm{T}_{3}\right)$ level in milking cows exposed to direct solar radiation. Journal of Central European Agriculture 4: 308-312.

16) Pusta, D., Stefan, R., Morar, I. and Pascal, I. (2006). Correlation between THI and rectal temperature in cows exposed to solar radiation. Buletin USAMV-CN, 63/2006: 141-145.

17) Radostits, O.M., Gay, C., Hinchcliff, K.W., Constable, P.D. (2007). Appendix-2. Reference laboratory values. Veterinary medicine, A textbook of the diseases of cattle, horses, sheep, pig and goats.Tenth edition. Elsevier, Edinburgh London New York. p 2049

18) Reena K, Dutt T, Patel M, Dey A, Poolangulam CC, Bharti PK and Barari SK (2016) Behavioural, biochemical and hormonal responses of heat-stressed crossbred calves to different shade materials, Journal of Applied Animal Research, 44:1, 347-354, DOI: 10.1080/09712119.2015.1074076 
19) Roland, L., Drillich, M., Iwersen, M. (2014). Hematology as a diagnostic tool in bovine medicine. Journal of Veterinary Diagnostic Investigation 2014, 26(5) 592-598.

20) Roy P K and Chatterjee A. (2010). Effect of different types of dairy cattle shelters on micro-climate variables in rural West Bengal. Indian journal of Animal Science 80(8): 781-784.

21) Sivakumar T, Suraj PT, Yasotha A, Phukon J.(2017). Identification of suitable housing system for dairy cattle in North East Zone of Tamil Nadu, India, with respect to microclimate, Veterinary World, 10(1): 1-5

22) Sinha R, Kamboj ML, Ranjan A and Devi I. (2019). Effect of microclimatic variables on physiological and hematological parameters of crossbred cows in summer season. Indian Journal of Animal Research. (53):173-177

23) Singh RR, Dutt T, Kumar A, Tomar A K S and Singh M. (2011). On-farm characterization of Vrindavani cattle in India. Indian Journal of Animal Sciences 81 (3): 267-71

24) Snedecor, F.W. and Cochran, W.G. (1994). Stastical Methods (8th ed.). Oxford and IBH Publishing Co.,Calcutta.

25) Shrikhande, G.B., Rode, A.M., Pradhan, M.S and Ashiesha, K. (2008). Seasonal effect on the composition of blood in cattle. Veterinary World 11(1):341-342.

26) Verma, K.K. (2015). Effect of microclimate modification on physiological, growth and behavioural performances of Murrah buffalo heifers during heat stress. Ph. D. Thesis, IVRI (Deemed University), Izatnagar, India.

27) Vijayakumar, P. (2005). Effect of thermal stress management on nutritional, physiological and behavioural responses of buffalo heifers. "Ph.D.Thesis" submitted to Deemed university, IVRI Izatnagar, Bareilly(U.P.) India.

28) Wise, M.E., Arllistrong, D.V., Huber, J.T., Hunter, R., Weirsma, F. (1988). Hormonal alterations in the lactating dairy cows in respons to thermal stress. Journal of Dairy Science 71(3):2480-85 